\title{
Hardy Hibiscus for Florida Landscapes ${ }^{1}$
}

\section{Gary W. Knox and Rick Schoellhorn ${ }^{2}$}

Hardy hibiscus are an overlooked group of perennials with tremendous potential for the landscape. Hardy hibiscus are herbaceous perennial members of the genus, Hibiscus. They are large-flowered, fast-growing plants up to 15 feet tall and 4 to 8 feet wide. They are close relatives of the tropical hibiscus (Hibiscus rosa-sinensis) seen commonly in the landscapes of southern and central Florida. Unlike their tropical counterparts, however, hardy hibiscus are much more cold hardy, vigorous, and long lasting, and they have larger flowers.

In north and central Florida, these plants emerge from the ground in mid to late spring and bloom from late spring through fall. With the exception of some of the herbaceous species, a hard freeze kills the above-ground growth but below-ground stems over winter and produce new shoots the following spring. Some species require freezing (chilling hours) to release vigorous new growth making them better suited for north and central Florida than for south Florida. Hardy hibiscus prefer full sun or partial shade and any soil that is not too dry. Hardy hibiscus are especially useful in areas where the soil is too wet for other perennials. In the landscape, they are often used as colorful, flowering specimen plants, as borders or as taller components of perennial gardens.
Many are well suited to semi-aquatic conditions and can be a great way to plant marshy areas that are otherwise maintenance problems. Some, such as swamp rosemallow (H. grandiflorus), are salt tolerant and are very adaptable to coastal areas. Hardy hibiscus is the perfect centerpiece plant in large mixed containers or planted alone. The bigger the container the bigger the impact it makes.

\section{Hardy Hibiscus Species}

Many Hardy Hibiscus are native to Florida and the southeastern United States, including comfortroot (Hibiscus aculeatus), scarlet rosemallow ( $H$. coccineus), swamp rosemallow (H. grandiflorus), halberdleaf rosemallow (H. laevis) and crimsoneyed rosemallow (H. moscheutos). These species are worthy of landscape use in their own right. Swamp rosemallow has rich fuzzy gray green leaves on a plant that reaches up to 15 feet in height. This species is salt tolerant and can grow in brackish water directly in the tidal zones. Flowers of $\mathrm{H}$. grandiflorus are about 8 to 10 inches across and a clear soft pink. Flowers of scarlet rosemallow are most commonly a clear red with petals that don't overlap, but the range of forms and closely related species will vary a lot.

1. This document is ENH999, one of a series of the Environmental Horticulture Department, Florida Cooperative Extension Service, Institute of Food and Agricultural Sciences, University of Florida. Original publication date October 10, 2005. Visit the EDIS Web Site at http://edis.ifas.ufl.edu.

2. Gary W. Knox Extension Specialist and Professor of Environmental Horticulture, University of Florida/IFAS, North Florida Research and Education Center, 155 Research Road, Quincy, FL 32351. and Rick Schoellhorn Floriculture Extension Specialist and Assoc. Professor of Environmental Horticulture, University of Florida/IFAS, Environmental Horticulture Department, 2523 Fifield Hall, Gainesville, FL 32611.

The Institute of Food and Agricultural Sciences (IFAS) is an Equal Opportunity Institution authorized to provide research, educational information and other services only to individuals and institutions that function with non-discrimination with respect to race, creed, color, religion, age, disability, sex, sexual orientation, marital status, national origin, political opinions or affiliations. U.S. Department of Agriculture, Cooperative Extension Service, University of Florida, IFAS, Florida A. \& M. University Cooperative Extension Program, and Boards of County Commissioners Cooperating. Larry Arrington, Dean 
Confederate Rose, Hibiscus mutabilis, is an old fashioned garden plant of the southern U.S. This upright, tree-like species grows up to 15 feet high and 10 feet wide in freeze-free areas of south and central Florida. In north Florida, heights of 6 to 8 feet are more common due to the annual hard freezes. Large-leaved and coarse-textured, confederate rose begins flowering in late summer producing 6- to 8-inch blooms that open white and fade to pink. One of its most notable features is that white, light pink and dark pink flowers can be found at the same time on any given plant. The most common form is 'Flora Plena' with double flowers, but a single-flowered form also can be found. Another cultivar of this species, H. mutabilis, Rubra, is a smaller statured plant (usually 4 to 6 feet in height) with single intense deep pink to carmine blooms.

Other Hardy Hibiscus species are grown for food or fiber as well as ornament. African Rosemallow (Hibiscus acetosella) has become popular as a foliage color annual in plantings around the U.S. Kenaf $(H$. cannabinus) is grown for its stem fibers that are used for making textiles or paper. A variety of kenaf formerly known as $H$. sabdariffa is a food plant with the common names of "Roselle," "Jamaica Sorrel" and "Florida Cranberry." The main edible part is the fleshy sepal, called a calyx, that surrounds the fading flower and developing seed capsule. The ornamental calyx is bright red and acid and is used to make tea, juice, jelly or a cranberry-like sauce.

\section{Commercial Hybrids}

Crimsoneyed rosemallow (Hibiscus moscheutos) and several other species have been used extensively in breeding programs. These hybrids produce spectacular flowers up to 12 inches across in shades of white, pink and red. Recent breeding programs are supplanting older cultivars such as 'Disco Belle Mix' and 'Southern Belle' with more vigorous cultivars such as 'Fireball'PP 13,631 and 'Super Rose'. These newer cultivars tend to grow smaller and more compact than the species. The 'Luna' series is exceptionally dwarf and available as a seed produced crop, while others like the 'Vintage' series are produced only by cuttings and offer new tones of deep cerise on dwarf plants. Some cultivars, such as 'Red Shield' and 'Kopper King'PP 10,793, have been selected for their burgundy to purple foliage.

\section{Characteristics of Hardy Hibiscus}

Characteristics of selected hardy hibiscus under evaluation in north Florida are listed in Tables 1 and 2. Other commercial cultivars include 'Anne Arundel', 'Cerise', 'Cranberry Punch'TM, 'Crimson Wonder', 'Crown Jewels'PP 11,857, 'Davis Creek', 'Flare', 'Giant Maroon', 'Pink Clouds', 'Plum

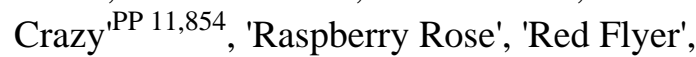
'Robert Fleming'PPAF, 'Royal Gems' and 'Sweet Caroline'.

\section{Care of Hardy Hibiscus in the Garden}

The major insect pest of hardy hibiscus is the caterpillar-like larva of the hibiscus sawfly, (Atomacera decepta). Several of these larvae often feed on the same leaf or plant and can quickly defoliate the entire plant. Other pests include whiteflies, mealy bugs, grasshoppers and spider mites. The primary diseases are various leaf spots caused by Cladosporium, Cercospora, Phyllosticta and other fungi.

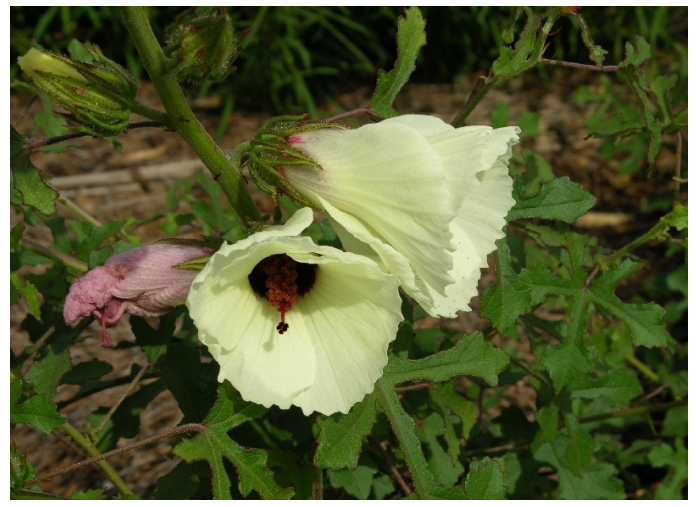

Figure 1. Comfortroot, Hibiscus aculeatus

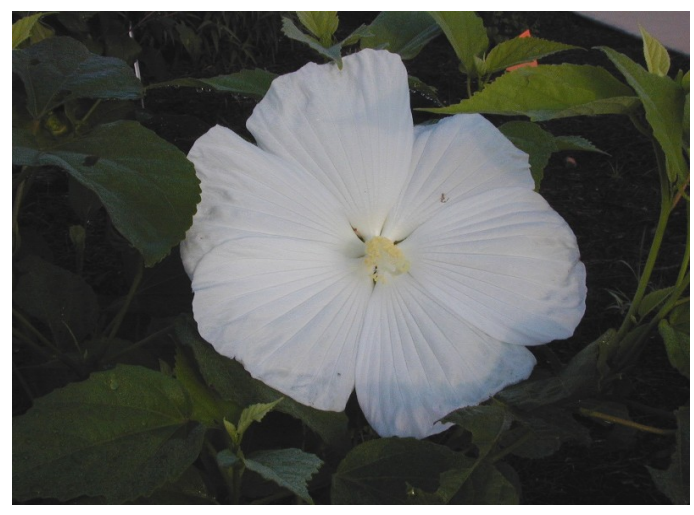

Figure 2. Hibiscus Blue River II 


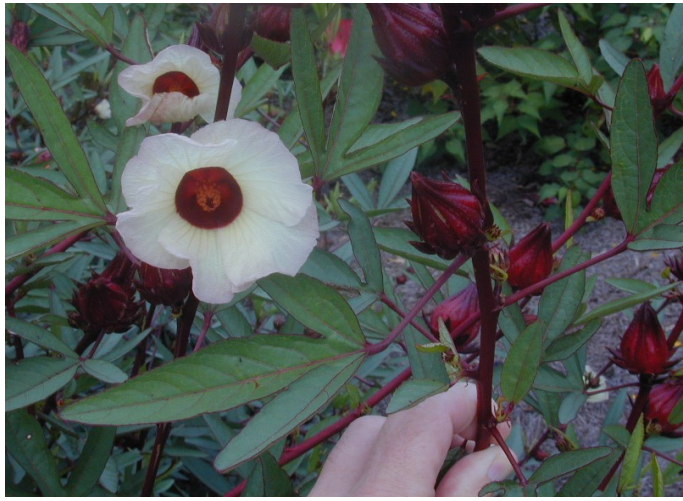

Figure 3. Hibiscus cannabinus

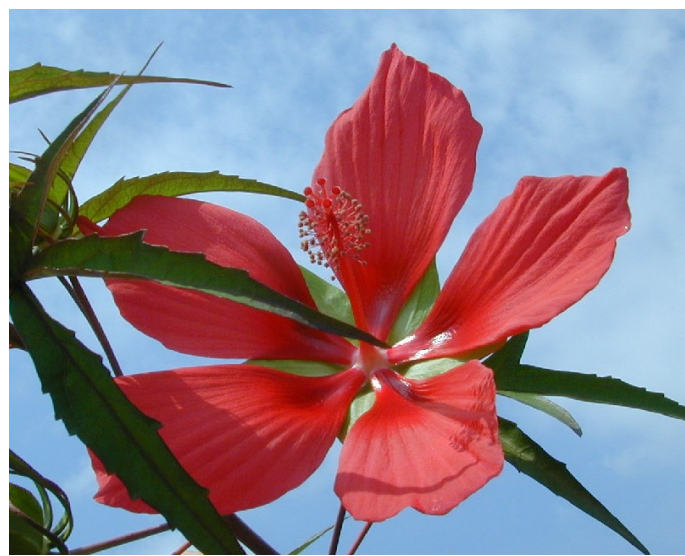

Figure 4. Scarlet rosemallow, Hibiscus coccineus

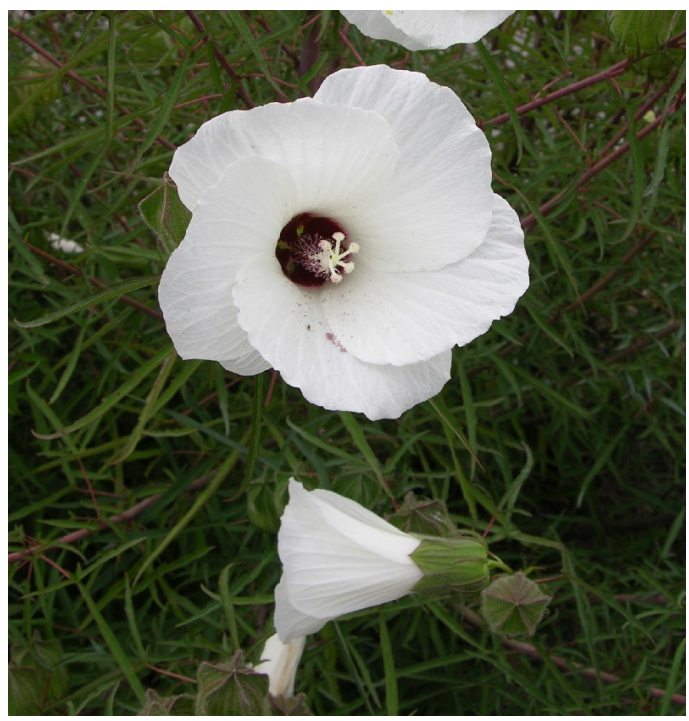

Figure 5. Neches River rosemallow, Hibiscus dasycalyx

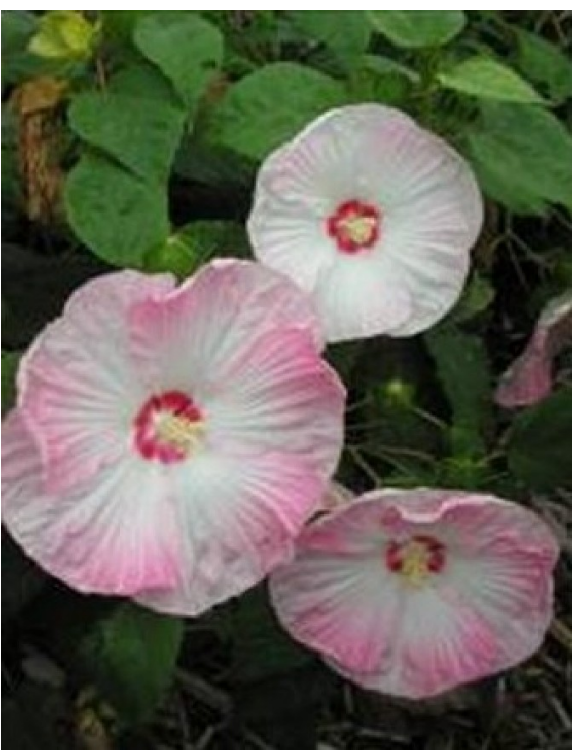

Figure 6. Hibiscus Disco Belle

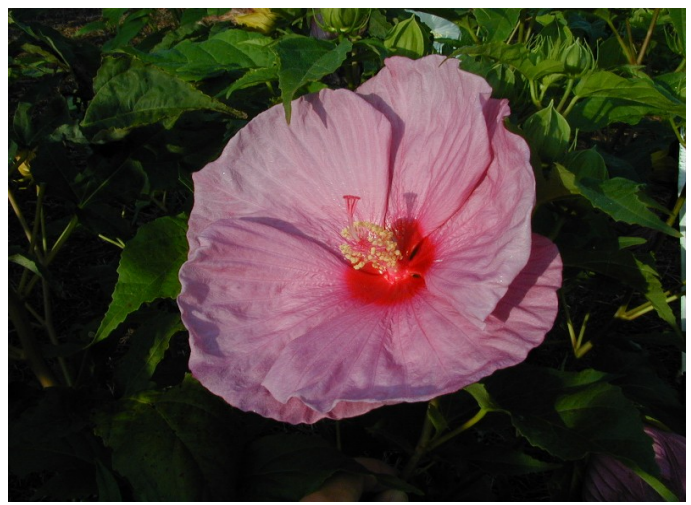

Figure 7. Hibiscus Fantasia

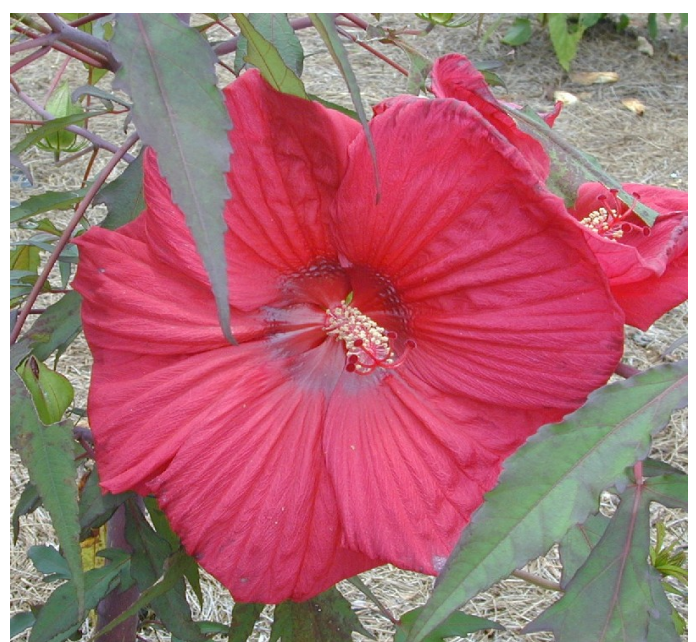

Figure 8. Hibiscus Fireball 


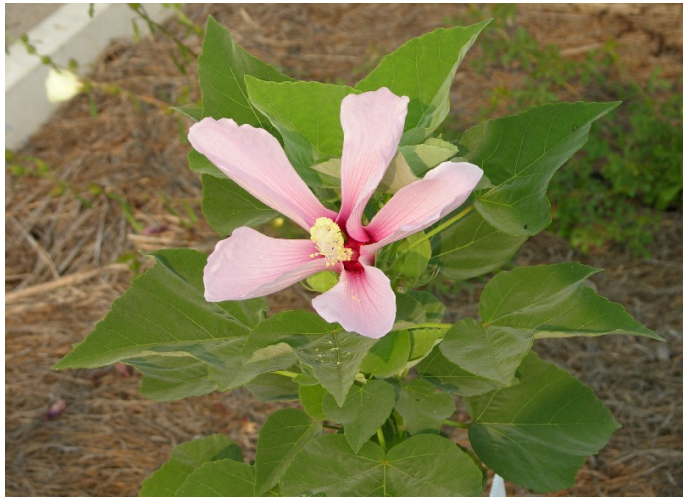

Figure 9. Swamp rosemallow, Hibiscus grandiflorus

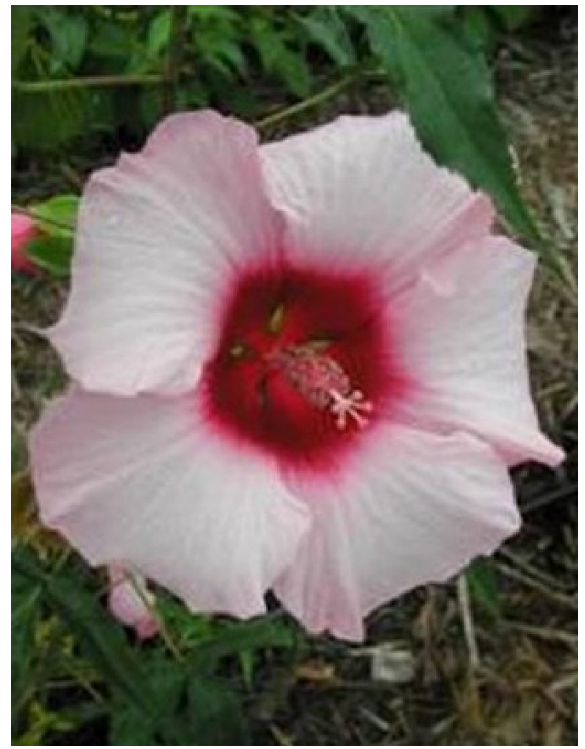

Figure 10. Hibiscus Lady Baltimore

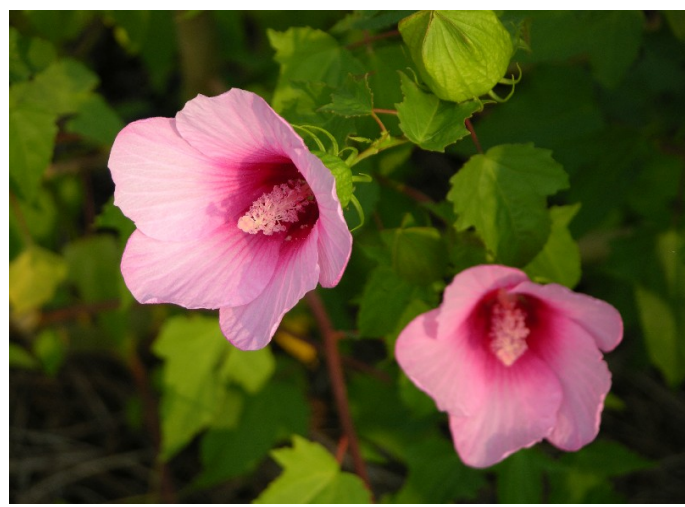

Figure 11. Halberdleaf rosemallow, Hibiscus laevis

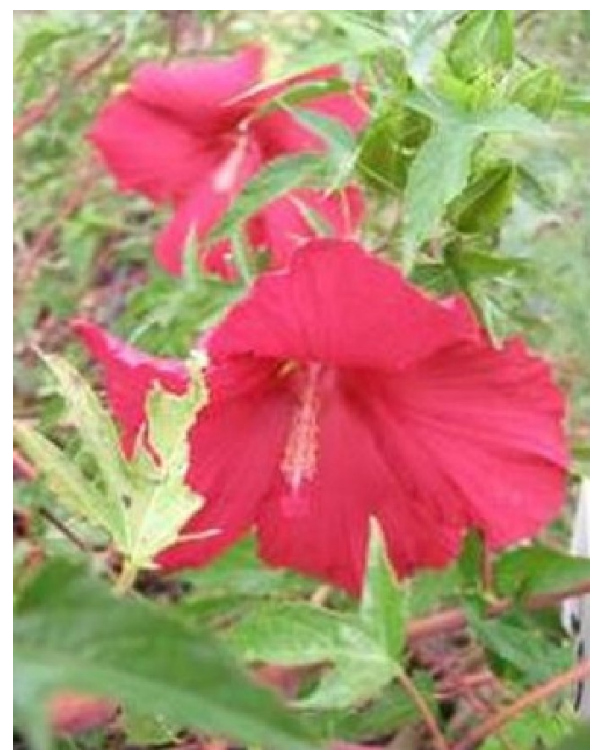

Figure 12. Hibiscus Lord Baltimore

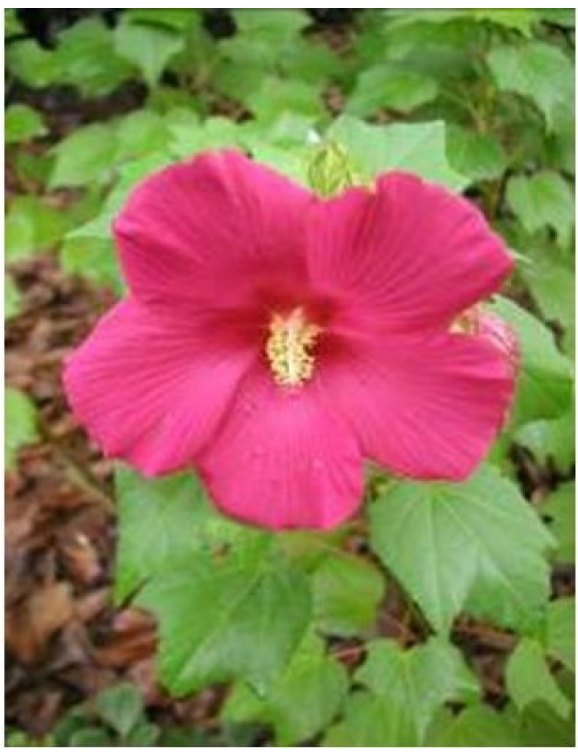

Figure 13. Hibiscus mutabilis Rubra

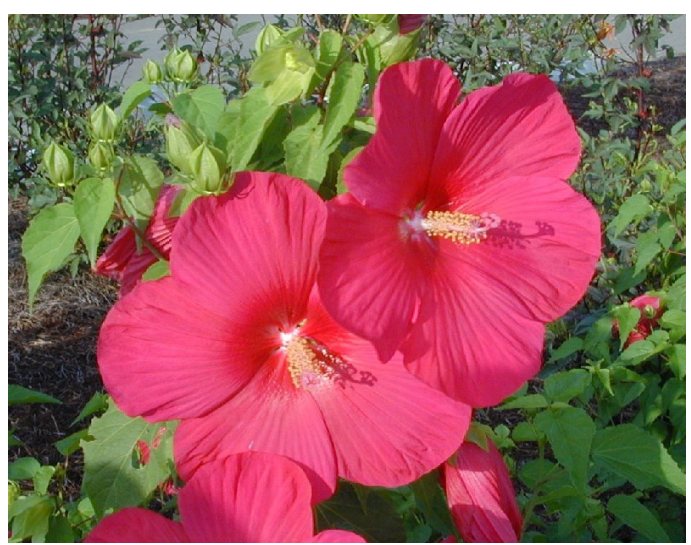

Figure 14. Hibiscus Super Rose 


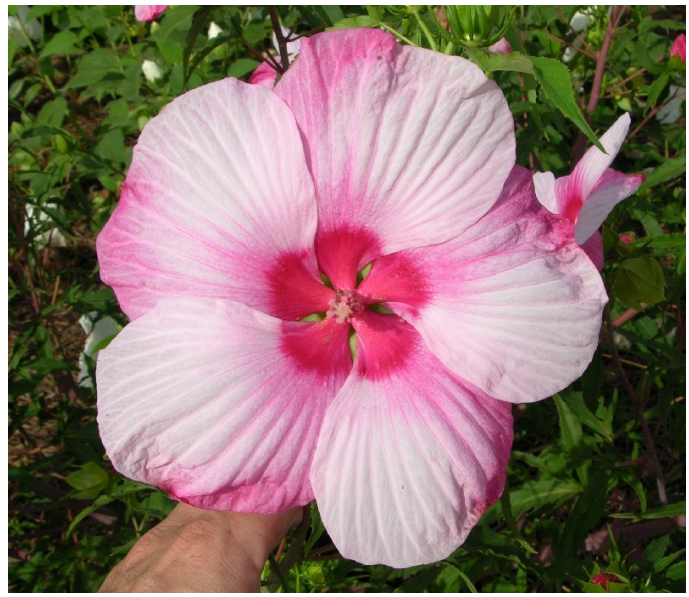

Figure 15. Hibiscus Turn of the Century

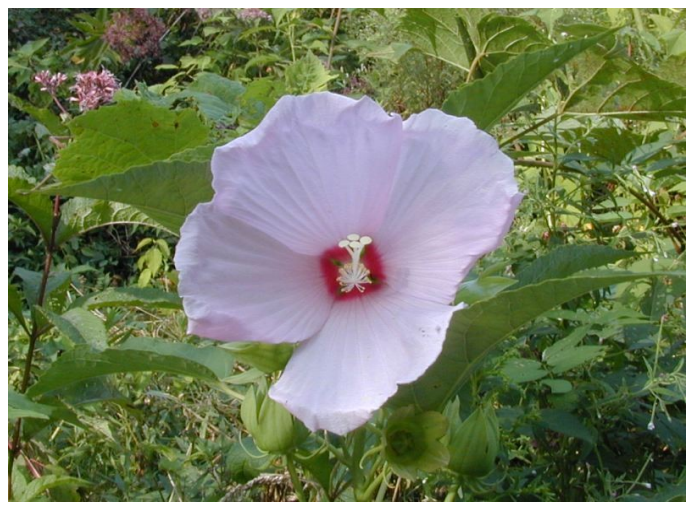

Figure 16. Crimsoneyed rosemallow, Hibiscus moscheutos 
Table 1. Characteristics of native or species forms of hardy hibiscus under evaluation at University of Florida/IFAS facilities.

\begin{tabular}{||l|l|l|l|l||}
\hline Species/Cultivar & Common Name & Flower Color & Habit & Trialing Location \\
\hline H. acetosella & African rosemallow & Yellow & Upright & Quincy, FL \\
\hline H. aculeatus & Comfortroot & Yellow & Spreading & Quincy, FL \\
\hline H. cannabinus & $\begin{array}{l}\text { Kenaf, roselle, Jamaica } \\
\text { sorrel, Florida cranberry }\end{array}$ & Yellow & Mounding & Quincy, FL \\
\hline H. coccineus & Scarlet rosemallow & Red & Very Upright & $\begin{array}{l}\text { Gainesville, FL } \\
\text { Quincy, FL }\end{array}$ \\
\hline H. dasycalyx & $\begin{array}{l}\text { Neches River } \\
\text { rosemallow }\end{array}$ & White & Mounding & Quincy, FL \\
\hline H. grandiflorus & Swamp rosemallow & Light pink with red eye & Very Upright & Gainesville, FL \\
Quincy, FL
\end{tabular}

Table 2. Characteristics of hardy hibiscus hybrids under evaluation at University of Florida/IFAS facilities.

\begin{tabular}{|c|c|c|c|}
\hline Cultivar/Species & Flower Color & Habit & Trialing Location \\
\hline Blue River II & White & Mounding & Quincy, FL \\
\hline Disco Belle Series & Red, blush, pink, white & Upright & Gainesville, FL \\
\hline Fantasia $^{P P 11,853}$ & Ruffled pink & Mounding & Quincy, FL \\
\hline Fireball $^{\mathrm{PP} 13,631}$ & Deep red & Upright & Quincy, FL \\
\hline Kopper King ${ }^{\text {PP 10,793 }}$ & Pale pink & Upright & Gainesville, FL \\
\hline Lord Baltimore & Red & Upright & Gainesville, FL \\
\hline Lady Baltimore & Pink & Mounding & Gainesville, FL \\
\hline Luna Series ${ }^{\text {PAF }}$ & Red, blush & Compact & Gainesville, FL \\
\hline Moy Grande & Pink & Upright & Gainesville, FL \\
\hline Old Yella ${ }^{\text {PPAF }}$ & Cream with a red center & Upright & Gainesville, FL \\
\hline Red Shield & Yellow & Upright & Quincy, FL \\
\hline Rio Grande & Solid red & Upright & Gainesville, FL \\
\hline Southern Belle & Red, blush, white, pink & Upright & Quincy, FL \\
\hline Super Rose & Rose pink & Mounding & Quincy, FL \\
\hline Turn of the Century & Pink/white bicolor & Upright & Quincy, FL \\
\hline$V$ intage ${ }^{\text {PAF }}$ & Red, white, pink, blush. & Compact & Gainesville, FL \\
\hline
\end{tabular}

